\title{
Vertebral chondrosarcoma in a blue-fronted parrot (Amazona aestiva)
}

\author{
Condrossarcoma vertebral em papagaio (Amazona aestiva)
}

\author{
Guilherme Reis Blume ${ }^{\mathrm{I}}$ Ayisa Rodrigues de Oliveira ${ }^{\mathrm{II}}$ Mariana Portugal Mattioli ${ }^{\mathrm{II}}$ \\ Letícia Batelli de Oliveira ${ }^{I}$ Janildo Ludolf Reis Junior ${ }^{I}$ Fabiano José Ferreira de Sant'Ana ${ }^{I^{*}}$
}

- NOTE -

ABSTRACT

Chondrosarcoma is a malignant mesenchymal tumor in which the neoplastic cells produce cartilaginous matrix and is uncommonly described in birds. This report describes the clinical and pathological findings of one case of chondrosarcoma in a blue-fronted parrot (Amazona aestiva). Macroscopically a $3.6 \times 3.5 \times 1.8 \mathrm{~cm}$, nodular, ulcerated, and firm mass was identified in the dorsal synsacrum. Microscopically, the mass was composed of a monomorphic proliferation of pleomorphic spindle chondrocytes with abundant cartilaginous matrix, consistent with chondrosarcoma.

Key words: oncology, psittacine, neoplasm.

RESUMO

Condrossarcomas são tumores mesenquimais malignos incomuns em aves, em que as células neoplásicas produzem matriz cartilaginosa. Este trabalho objetiva descrever os achados clínico-patológicos de um caso de condrossarcoma em um papagaio verdadeiro (Amazona aestiva). $O$ animal apresentou aumento de volume progressivo na região dorsal do sinsacro. Macroscopicamente, notou-se uma massa firme, irregular, ulcerada, medindo 3,6x3,5x1,8cm. A histopatologia revelou proliferação monomórfica de condrócitos fusiformes e pleomórficos, com abundante matriz cartilagionasa, compativel com condrossarcoma.

Palavras-chave: oncologia, psitacídeo, neoplasma.

Chondrosarcoma is a malignant mesenchymal tumor that produces cartilaginous matrix. This tumor is uncommonly described in birds, but is more frequently reported in dogs and rarely in other species (DITTMER et al., 2012; THOMPSON \& POOL, 2002).

There are no reports of chondrosarcoma in parrots and few descriptions in other bird species, such as ruffed grouse (Bonasa umbellus) (SIEGFRIED, 1983), great egret (Ardea herodius occidentalis and Ardea alba) (SPALDING \& WOODARD, 1992; KUBO et al., 2007), yellow-collared macaw (Ara auricollis) (KENNEDY et al., 1995), chicken (Gallus gallus domesticus) (DITTMER et al., 2012), and pheasant (Phasianus colchicus) (ERDOĞAN et al., 2013).

Chondrosarcomas commonly arise from any structure derived from cartilaginous precursors. In some cases, it may be originated in areas where there is no cartilage. The tumor presumably develops in soft tissues from the cartilaginous differentiation of primitive mesenchymal cells (ERDOĞAN et al., 2013). In dogs, flat bones of the skull, ribs, and pelvic bones are more frequently affected (BRODEY et al., 1974).

Histopathology is essential to diagnose and differentiate chondrosarcoma from other neoplastic, inflammatory, and degenerative processes in bone when clinical and radiographic findings are inconclusive (THOMPSON \& POOL, 2002).

This report describes the clinical and pathological findings of a rare case of vertebral chondrosarcoma in a blue-fronted parrot (Amazona aestiva).

'Laboratório de Patologia Veterinária (LPV), Universidade de Brasília (UnB), Campus Universitário Darcy Ribeiro, 70910-900, Brasília, DF, Brasil. E-mail: santanafjf@yahoo.com.*Corresponding author.

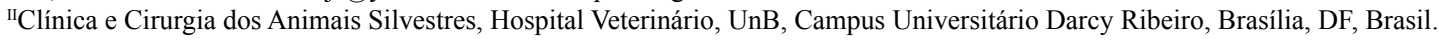


A 24-year-old male blue-fronted parrot presented a history of swelling in the dorsal synsacrum. On clinical examination, a $3.6 \times 3.5 \times 1.8 \mathrm{~cm}$, firm, ulcerated, and irregular nodule was identified in the synsacrum. The lesion was painful, indicated by the bird pecking at the affected region, resulting in local ulcers and a worsening of its clinical condition. Radiographic examination more precisely localized the lesion and revealed a well-circumscribed, radiodense nodule with no evidence of metastasis to other organs (Figure 1A). Surgical excision of the nodule was performed (Figure 1B). Anesthesia was induced using midazolam (2mg $\mathrm{kg}^{-1}$, Midazolam ${ }^{\circledR}$, Hipolabor, Sabará/MG, Brazil) and butorphanol (1 $\mathrm{mg} \mathrm{kg}^{-1}$, Torbugesic ${ }^{\mathbb{B}}$, Zoetis, Campinas/ SP, Brazil), and maintained with inhaled isoflurane (Isoflurano ${ }^{\circledR}$, Instituto BioChimico, Itatiaia/RJ, Brazil) delivered in a universal vaporizer. Macroscopically the cut surface of the nodule showed irregular white and black coloration intraoperatively. The mass was fixed in buffered $10 \%$ formalin, routinely processed, and stained with hematoxylin and eosin.

Microscopically, the superficial and deep dermis was expanded and replaced by a discrete, non-encapsulated, infiltrative mass. The lesion was composed of plump spindle cells (mesenchymal cells) arranged in multiple lobules containing clusters of cells surrounded by abundant cartilaginous matrix and mild stroma. The neoplastic cells had a moderate amount of light, basophilic, and vacuolated cytoplasm (Figures 1C and 1D). The nuclei were oval or elongated, with loose chromatin and multiple prominent nucleoli. There was moderate anisocytosis and rare mitotic figures. Additionally, a focal area of epidermal necrosis and ulceration, and multifocal

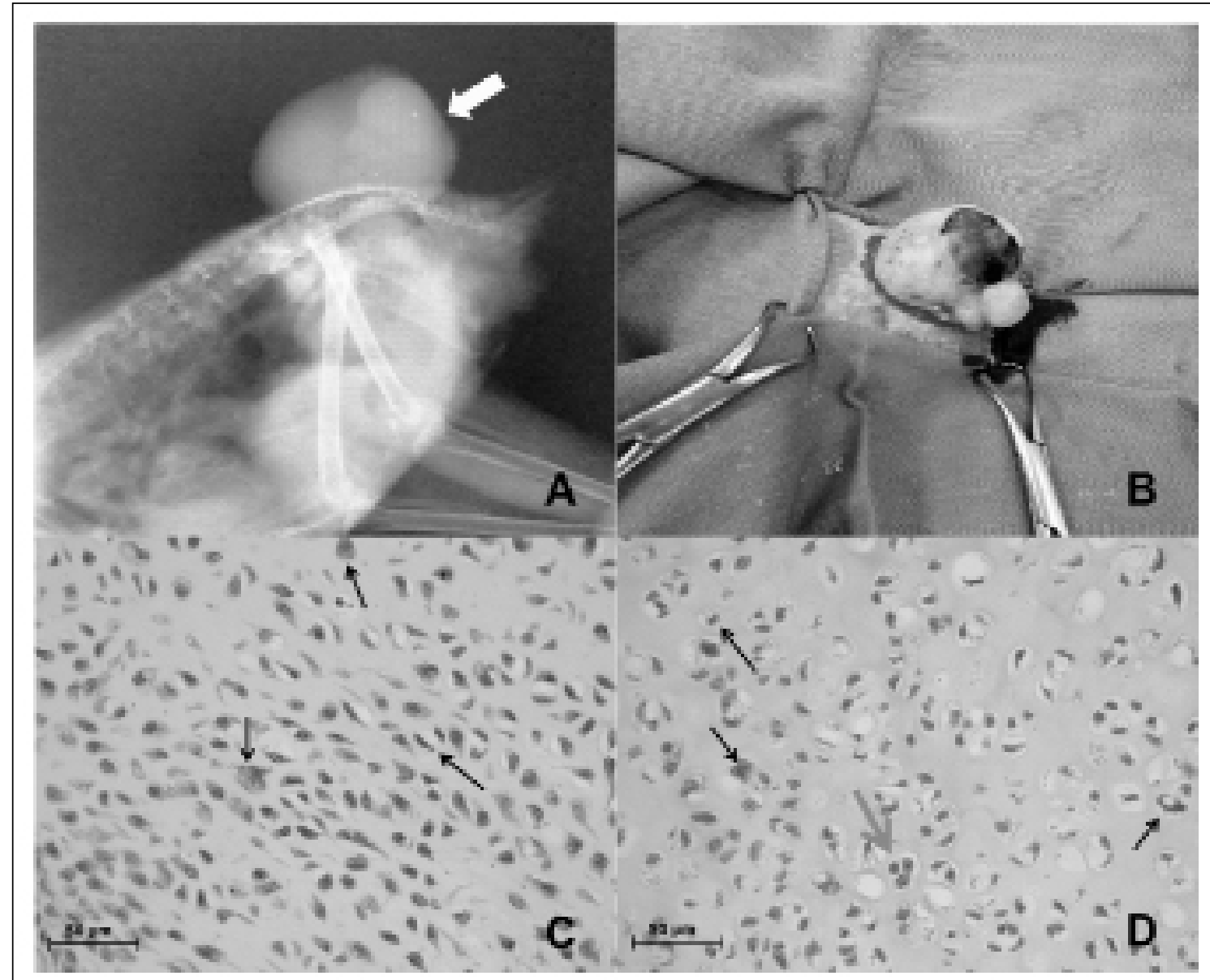

Figure. 1 - Blue-fronted parrot (Amazona aestiva), vertebral chondrosarcoma. A. Radiographic examination reveals an oval, radiodense, neoplastic mass affecting the synsacrum (arrow). B. Gross intraoperative examination of the neoplasm before excision shows the irregular and ulcerated surface. C and D. Histopathologic examination reveals a hypercellular, basophilic chondroid matrix with numerous gaps containing spindle and pleomorphic chondrocytes (black arrows). Some contain three neoplastic chondrocytes (yellow arrow). Hematoxylin and eosin. 
areas containing a moderate deposition of fibrous, amorphous, and eosinophilic material (fibrin), hemorrhage, and congestion were noted.

Despite the poor prognosis, the bird recovered normally from anesthesia and improved clinically postoperatively. Recurrence was not observed during 6 months postoperatively. Based on the clinical and histopathologic findings, the bird was diagnosed with chondrosarcoma.

Neoplasia encompasses approximately 3.8 to $5.4 \%$ of all diseases affecting psittacines kept in captivity (LATIMER, 1994; GODOY et al. 2009). The main neoplasms diagnosed in these birds are lipomas, papillomas, fibrosarcomas, hemangiomas, hemangiosarcomas, cholangiocarcinomas, lymphomas, leiomyomas, leiomyosarcomas, and carcinomas (LATIMER, 1994; GODOY et al. 2009).

There is evidence that the avian leucosis/ sarcoma virus group can induce sarcoma, including chondrosarcoma, in birds (PAYNE, 1998; KUBO et al., 2007). However, there is no proof of viral involvement in the development of chondrosarcoma in parrots. In addition, there is little information detailing the etiology, predisposing factors, biological behavior, and appropriate treatment of neoplasia in pet birds (LATIMER, 1994).

The pathological findings observed in the present case are similar to those described for chondrosarcomas of other affected domestic animals (DITTMER et al., 2012; THOMPSON \& POOL, 2002). In other birds, chondrosarcomas have been described in the metatarsophalangeal joint (SIEGFRIED, 1983), nictitating membrane (SPALDING \& WOODARD, 1992), tarsal bones (KENNEDY et al., 1995), carpus (KUBO et al., 2007), sternum (DITTMER et al., 2012), and ventriculus (ERDOĞAN et al., 2013). Involvement of the vertebral notch, as in the present case, is uncommon (DITTMER et al., 2012). Chondrosarcomas have low to moderate metastatic potential in dogs, whereas canine osteosarcoma frequently metastasizes. Apparently, the metastatic potential of chondrosarcoma is low in birds because metastasis has not been observed in other reports (SIEGFRIED, 1983; SPALDING \& WOODARD, 1992; KENNEDY et al., 1995; KUBO et al., 2007; DITTMER et al., 2012; ERDOĞAN et al., 2013), similar to the current case. Some authors report that this neoplasm is locally infiltrative in birds but is less aggressive compared to chondrosarcomas in other species (DITTMER et al., 2012). Chondrosarcoma cases have been reported infrequently in birds, and this appears to be the first description of chondrosarcoma in the parrot.

\section{REFERENCES}

BRODEY, R.S. et al. Canine skeletal chondrosaroma: A clinicopathologic study of 35 cases. Journal of American Veterinary Medical Association, v.165, n.1, p.68-78, 1974.

DITTMER, K.E. et al. Primary bone tumors in birds: a review and description of two new cases. Avian Diseases, v.56, n.2, p.422426, 2012. Available from: <http://dx.doi.org/10.1637/9854071911-Case.1>. Accessed: Mar. 19, 2014. doi: 10.1637/9854071911-Case. 1

ERDOĞAN, O. et al. A case of chondrosarcoma in pheasant (Phasianus colchicus). Turkish Journal of Veterinary and Animal Science, v.37, p. 242-244, 2013. Available from: <http:// journals.tubitak.gov.tr/veterinary/issues/vet-13-37-2/vet-37-221-1202-22.pdf>. Accessed: Mar. 18, 2014. doi: 10.3906/vet$1202-22$.

GODOY et al. Principais processos neoplásicos encontrados em psitacídeos mantidos em cativeiro. Pesquisa Veterinária Brasileira, v.29, p.445-451, 2009. Available from: <http://www. scielo.br/pdf/pvb/v29n6/01.pdf>. Accessed: Mar. 20, 2014. doi: 10.1590/S0100-736X2009000600001.

KENNEDY, F.A. et al. Synovial sarcoma in Moluccan cockatoo (Cacatua moluccensis) and a chondrosarcoma in a yellow collar macaw (Ara auncoilis). Veterinary Pathology, v.32, n.5, p.560, 1995. Available from: <http://vet.sagepub.com/ content/32/5/545.citation>. Accessed: Mar. 19, 2014. doi: $10.1177 / 030098589503200517$.

KUBO, M. et al. A case of chondrosarcoma in a free-flying great egret. Journal of Wildlife Disease, v.43, n.3, p.542544, 2007. Available from: <http://www.jwildlifedis.org/doi/ pdf/10.7589/0090-3558-43.3.542>. Accessed: Mar. 20, 2014. doi: $10.7589 / 0090-3558-43.3 .542$.

LATIMER, K.S. Oncology. In: HARRISON, G.J Avian medicine: principles and application. Lake Worth: Wingers Publishing, 1994. p.642-660.

PAYNE, L.N. Retrovirus-induced disease in poultry. Poultry Science, v.77, n.8, p.1204-1212, 1998. Available from: <http:// ps.oxfordjournals.org/content/77/8/1204>. Accessed: Mar. 20, 2014. doi: $10.1093 / \mathrm{ps} / 77.8 .1204$.

SIEGFRIED, L.M. Neoplasms identified in free-flying birds. American Association of Avian Pathologists, v.27, n.1, p. 8699, 1983. Available from: <http://www.jstor.org/stable/1590375>. Accessed: Mar. 18, 2014. doi: 10.2307/1590375.

SPALDING, M.G.; WOODARD, J.C. Chondrosarcoma in a wild great white heron from southern Florida. Journal of Wildlife Disease, v.28, n.1, p.151-153, 1992. Available from: <http:// dx.doi.org/10.7589/0090-3558-28.1.151>. Accessed: Mar. 18, 2014. doi: 10.7589/0090-3558-28.1.151.

THOMPSON, K.G.; POOL, R.R. Tumors of bones. In: MEUTEN, D.J. Tumors in domestic animals. 4.ed. Ames, IA: Iowa State University, 2002. Cap.5, p.245-317. 